\title{
The Nene Valley a Roman Frontier, and the Origin of the Name Northampton
}

the Rev. R. S. Baker B.A.

To cite this article: the Rev. R. S. Baker B.A. (1878) The Nene Valley a Roman Frontier, and the Origin of the Name Northampton, Archaeological Journal, 35:1, 339-352, DOI: 10.1080/00665983.1878.10851834

To link to this article: http://dx.doi.org/10.1080/00665983.1878.10851834

冓 Published online: 14 Jul 2014.

Submit your article to this journal $\lceil\pi$

Q View related articles $₫$ 
THE NENE VALLEY A ROMAN FRONTIER, AND THE ORIGIN OF THE NAME NORTHAMPTON.1

By the Rev. R. S. BAKER, B.A.

Cinctosque castris Antonam et Sabrinam Aluvios cohibere parat.

The county of Northampton is oddly shaped. It stretches for nearly seventy miles right athwart England, and goes far to span over the space between the Wash and the Bristol Channel. From the western-most edge of Northants to the nearest point of the Severn, Tewkesbury, is barely over thirty-five miles.

It has sometimes occurred to me that its shape and direction might be due to the tradition surviving to Saxon times, of its being the border land of the Romans at one period of their history in Britain. Certain it is that the line this county takes-- rudely regardless of all other counties-is coincident with the Roman fortified frontier, tempore Claudius, for over sixty miles.

This mid-England fiontier, being but a temporary one, was not marked by a continuous wall and fosses, as that gigantic work in Northumberland, but. by a chain of strong-walled camps, connected by a continuous roadway leading from one to the other, and having the Nene river, as far as it went, for an outer line of defence on the side next the enemy The period of its erection was an early one, viz., about the year 47 or 48 of the Christian Era, i.e., about fifteen years after the Crucifixion. And this makes these traces of Roman occupation, still legibly stamped upon the Nene Valley, the more venerable and interesting.

What is most fortunate as regards this point of history is that the book of the Annals of Tacitus, containing the account of it, has not been lost (as the preceding book has), but still survives - a precious fragment of history for Englishmen.

' Read in the Section of Antiquities at the Ammul Meeting at Northampton, July 30 th, 1878. 
To make my story clear, I had better glance for one minute at the history of the Roman invasions. The first attempt upon Britain was made by Julius Crsar, before Christ 54. $\mathrm{He}$ "came and saw," and that was nearly all. He imposed a tribute on the South-Eastern tribes, but it was never paid, and Britain was left to herself for near one hundred years more. In the meantime she was learning something from her would-be conquerors, and from her Gaulish neighbours, who were under the Roman rule. Cunobelin (Shakespeare's Cymbeline), who reigned over Southern Britain when our Lord was working at the carpenter's bench, was said to have been educated at Rome. He had coins much like the Roman ones, and reigned over a people considerably leavened by the contiguity of Roman civilization.

But the Romans were not the people to let the Britons off' so easily. The mystery which, in Roman minds, lay round this great and beautiful island of the extreme west (they were not quite sure that it was an island), with her white cliffs and boisterous, "monster-abounding," seas, and above all the occasional taste of her oysters' at Roman suppers, not to mention her pearls, all combined to make it certain that Britannia must one day stoop her proud neck to the Roman yoke. That day came at last in the reign of the Emperor Claudius.

About ten years after Roman soldiers had vainly guarded a sepulchre at Jerusalem, and St. Paul was just beginning his labours on the coasts of the Mediterranean, and Nero was a harmless boy playing in the Imperial gardens at Rome, the edict went forth for the conquest of Britain. The Emperor chose Aulus Plautius, with Vespasian for his second in command, to conduct this second invasion of our island. In three or four years of hard fighting they succeeded in subduing the whole of the South and Southern Midlands; Claudius being sent for to put the finishing stroke to the war in person, thus easily gaining for himself and his son the title of "Britannicus," and the honour of a triumph at Rome.

Unfortunately, as mentioned above, the eleventh book of the Annals of Tacitus, containing the narrative of

${ }^{1}$ Hor. Carm. lib iv; ode 14.

- Jut. sut., iv; 140.

"See Suetonius, and Marbodceus. 
this campaign, has perished, and with it details of extreme interest to English readers.

P. Ostorius Scapula succeeded Plautius as commanderin-chief in Britain, most probably in the year 47 . He arrived late in the autumn, and found confusion worse confounded reigning in the island. The unconquered tribes of the Northern Midlands, and of the North and North West, were making violent raids upon the allied territories, thinking themselves pretty safe from reprisals, till the winter was over at all events. They little knew their man! The general gathered a few trusty and lightarmed battalions, and by rapid marches, pounced suddenly upon the invaders, routed them, and drove them back into the forests of Northamptonshire and Warwickshire; and then, in order to make the Southern half of Britain safe for the future against such attacks, he resolved on a great work, and forthwith took steps for carrying it out-probably early in 48-and that work was the rumning of a line of forts right across Britain, in its narrowest part-from where the Fens and the Wash encroach upon the land on the east, to where the great Severn estuary cuts deep into the island on the west; a project rendered easier by two rivers, which, taking their rise close together in the heart of Britain, flow severally, the one east and the other west, into those two estuaries.

As this is the most important point of my story, and as it is in fact the proposition which I have to make good, viz., that our Nene valley camps are a portion of the Ostorian line mentioned by Tacitus; I think it will be the best to read a free translation, revised and approved by a good classical scholar, of the passage of Tacitus relating to the transaction. Tac. Ann. xii, 31, fiee translation. "But in Britain a troubled state of affairs greeted the arrival of the new preprætor, $P$. Ostorius. The enemy had overflowed their bounds, and poured their hostile bands upon the territories of our allies. And this with the more reckless violence, as they deemed that a new general, a stranger to his troops, and at the commencement of winter, would never take the field against them at once. He, however, aware that first acts are those which make an impression, and beget respect or contempt as the case may be, hurries 
into the field some light-armed cohorts, and after slaughtering those who ventured to make a stand, followed up the routed and separated bodies of armed men, so that they should not again coalesce; and, knowing that neither general nor soldier would ever get a moment's quiet under a distasteful and fictitious peace, he proceeded to disarm the suspected tribes, and take steps for fencing in the Nene and Severn rivers by a chain of fortified camps. This latter proceeding the Iceni were the first to object to, a strong tribe, and unweakened by battles with the Romans, for they had from the first voluntarily sought our alliance. Under their leadership the surrounding "peoples chose with them as a battle field a certain spot." . . . . And then he goes on to describe a severe battle that took place at the spot aforesaid, Valpy thinks somewhere in Huntingdonshire(I have some reasons for thinking it may have been at Covington, near Kimbolton) ; and after the enemy had received there a severe punishment, and the doubting tribes had consequently all given in, the Nene Valley works were able to proceed.

The above translation is from the edition of Valpy, and there the text which mentions the two rivers runs as follows: "cinctos que castris Antonam et Sabrinam fluvios cohibere parat;" which I take to mean, that he brought those rivers together (co-habeo) and made one of them, so to speak, by running a line of camps along each and from one to the other, thus confining or fencing them in (in a second sense of co-habere) by a girdle or cincture made of forts and rivers, or rather confining the people who lived beyond that cincture.

I think that the best and tersest way of construing this vexed and difficult passage is "He proceeded to sonfine the rivers Nene and Severn within a cincture of camps.'

I am quite aware that this is a disputed passage, and that there are various readings of it. I will not, however, discuss them now. All I shall say is, that I have consulted many editions of Tacitus, ancient and modern, foreign and English, and have come to the conclusion that, whatever reading we take, it makes no practical difference. Take which you will, and we cannot help seeing what Tacitus is trying to tell us, and that is :- 
1. That Ustorius' object was to make South Britain safe against the North.

2. To this end he drew a line of forts from somewhere to somewhere else.

3. That two British rivers, which he names, were in comnection with these forts.

The Salnina, one of them, no one has ever doubted ahout. The Antona, a little reflexion will tell us, must be the Nene and no other. The context before and after, the military situation, and strategical reasons, demand this conclusion. A glance at the map of England shows that there was no better line at which to fortify one half of England against the other, for nature has made half of our "scientific frontier" for us. And so we find that the ablest commentators on Tacitus, including Camden, have concluded, that though they are at a loss to explain Antona, yet they are sure he means the Nene. This opinion is confirmed by our great writer on Roman military antiquities in Great Britain, General Roy; who looking the question professionally, has no doubt that the Nene was intended by Tacitus. To draw the line from the Severn to the Bristol Avon, or the Hampshire Avon, as some have done, appears to me simply absurd. But Camden is to blame for putting people on the track of the Avons. England is a little country compared with some with which the Romans had to deal, and they were not the people to nibble at the corners of it in that timid fashion.

If no other proof were forthcoming, there is proof enough in the fact that the Iceni (Ikeni I suppose we should call them) objected to the work. The Iceni occupied the Eastern Counties, and Huntingdon and Cambridge shires (as I think is always granted); they would have known little and cared less about a line right-away in the west. But when these Nene forts were threatening to stare them in the face, and to cut them off from old friends on the other side, looking much like a coming subjection of the whole land: then they came to the serious conclusion to throw up the Roman alliance, and resist the measure to the death. As a practical clincher to the whole argument, we find a series of camps-some of them large and strongly-walled-at pretty regular in- 
tervals, all up the Nene Valley, and, what is more emphatic, all on the hither or right bank of the river, from near the old edge of the Fens to overthwart Northampton.

Irchester is one of these Ostorian camps. It is twenty acres in extent, and wherever we cut the vallum, we find the massive foundations of the walls. Coins from Claudius, down to the end of the Roman power in Britain, are picked up there in abundance. The bed of the old Nene is at the foot of the northern wall. These camps are at intervals of about seven miles. The next below Irchester is Cotton, in Ringstead parish, where, half-a-mile further down, is a second smaller fort, close to a ford still existing over the Nene. Then, still going down, comes a gap of sixteen miles; there ought to be a camp somewhere about Achurch, and true enough, Mr. Hodgson, Rector of Pilton, and I discovered some rectangular earthworks in a wood of Lord Lilford's, called the Lynches, on the right bank, but this requires more examination. Not far off, on the other side of Lord Lilford's park, have latel $y$ been discovered Roman interments, pottery, and coins, in digging for stone.

About ten miles below Lilford we find Chestertom Camp, on the right, or Huntingdonshire bank of the Nene, just opposite the later city of Durobriva (Castor), which is on the Northants side of the river. This camp, I believe, was originally walled; the vallum is still very clearly marked, though it has been ploughed over for ages. Five miles lower we reach Peterborough, and hard by that town was the ancient edge of the Fen.

The road connecting these camps is still traceable in many places, untably so from Cotton to Stanwick, a village which (anciently written Stanweg) takes its nume from this way. In many places the Roman way is no doubt identical with our present roads.

Six and a half miles above Irchester we come to Cogenhoe (pronounced Cookno), where, according to Mr. Simpkinson, the late Rector of Brington-(I quote from a most interesting lecture of his given in Northampton in 1862)-are traces of Roman occupation. I have not, however, been able to discover these myself, and I shall not venture to make any assertion respecting them. 
That this village would have formed a splendid position for a camp admits of no manner of doubt. But a mile and a half above Cogenhoe we find a strong Roman outpost, or fort, in the form of an artificial hill, called Clifford's Hill-evidently from its name, in connection with some ford, which it was requisite to watch. This mound rises from the meadows sixty feet from the water, and has an area of about ninety feet on its top.

Six miles above Cogenhoe we come to the country opposite Northampton, and at this town may have been a British fort, which required watching. Bridges thinks there are traces of Roman occupation somewhere near Queen Eleanor's Cross; but this, with Cogenhoe and Lilford, requires investigation. But might not Hunsbury, half a mile higher up, have been a British fort, occupied by Ostorian troops? The Romans were never slow to occupy strong positions of the enemy, though opposed to their own theories of the proper form of a camp.

But I do not feel myself responsible for Ostorius when he gets above Irchester. I must leave quaint old Morton, or our friend Sir Henry Dryden, to trace out the line of Ostorius through the high lands of Northamptonshire, in the direction of the Severn; these are certainly not wanting, many strong Roman positions trending in that direction ; but these are beyond the scope of the present paper.

It should be mentioned that, in probable connection with these Nene forts, are several speculæ or signal hills, formed like large tumuli, with a foss surrounding them, and occupying positions commanding the Nene Valley for many miles; notably, one on high ground in Chesterton parish, commanding a view from Peterborough on one side, to the high ground above Lilford on the other. Another in the village of Wollaston overlooks the Nene Valley from Higham to Northampton. If this strong line of camps on the hither side of the Nene, with a connecting road and signal stations, are not the forts mentioned by Tacitus, what are they? When were they made? and for what purpose? No one has yet answered these questions. Can they be answered? I think not. 


\section{Origis of the name Northampton.}

We now come to the word Antona.

This name has always been a stumbling-block, for it does not look at all like the word Nene There is an $\mathrm{N}$ in both, and that is all that can be said. The great Camden jumps to the conclusion that Tacitus must have written Aufona, which, by dropping out the $\mathrm{U}$, would be $\Lambda$ fona-the Latinisation of Afon or Avon-the British word for river-meaning thereby the Nene, whose then proper name did not reach Tacitus, or else he mistook Avon for a proper name. If we examine, however, the actual words of Cumden, we shall find that this new reading was put forward with apology, and with no great assurance. His words are (quoting from Bishop Gibson's translation, for I have had no opportunity to see the original) : "Higher in the country (i.e. Northants) northward, arises the river Aufona or Avon (for Avon in the British tongue is the general name for all rivers). It is called the Nen by the inhabitants." . . . . A very noble river it is, and if I guess right, it was garrisoned in old time by the Bomans; for when the hither part of Britain, in the Emperor Claudius' time, was brought under the Roman government, so as the inhabitants thereof were termed allies to the Romans, when the more remote Britains also made frequent incursions into this country, and carried all before them ..... then P. Ostorius (says Tacitus) cinctos castris Antonam (Aufonam I would read, if I might take that liberty) et Sabrinam cohibere parat. . . . "What river this should be none can tell. Lipsius (the Apollo of our age) hath either dispelled this mist, or I am in a cloud. He points out Northampton.'

It so happened that I came on this Northampton theory for Antona, from my own inner consciousness, before I had seen Camden or Lipsius; and, of course, I felt much corroborated when I found the Apollo of the 16th century on my side. Lipsius' own words are (quoting from the Tacitus of Augustus Ernest, Leipsic $177^{2}$, where the disputed text is the same as Valpy's, cinctos que castris, \&c), "Antona sane civitas videtur, manetque hodie Northamptona." That is, "Antona in- 
deed seems to be a town, and remains to this day by the name of Northamptona."

It is worthy of notice that, in discussing different readings of the passage (such as Sabriana for Sabrina, in Ptol.), Lipsius gives not the slightest hint that he had ever met with another reading for Antona; nor do I believe that one was ever heard of till Camden came. In spite of Lipsius, Camden does not quite emerge from his cloud, for he sticks to his Aufona, and with admirable inconsequence, goes on, "and I am of opinion that Antona hath crept into Tacitus instead of Aufona, upon which Northampton is seated." Then when he gets to the town of Northampton (p. 518), he gives his own derivation of Northampton, "where, at their very meeting (i.e., the North and South Nene) the town called from the river, North-afan-ton, and by contraction Northampton, is so seated, \&c." . . . .

His editor Gibson (who mixes his text up with Camden's in the most disagreeable manner), here cuts in to deny any Celtic derivation whatever to Northampton; he asserts it to be Saxon, and cites Southampton as a parallel case.

Most unfortunately, Camden's mere suggestion about Aufona has been taken for the conclusion of infallible authority by most people since. Editors, commentators, antiquaries, history writers, from that day to this, in a long string, like sheep filing through a gap one after another, follow their leader with amusing fidelity. Thus he has done, unwittingly, a great deal of mischief, and illustrates in his own person an evil, which in his Preface he is thoroughly on his guard against; there he says, "It is possible that I may have been led into errors by the authority of writers, whom I reckoned I might safely rely on. 'There is nothing more dangerous (says Pliny) in the search after truth, than when a staunch author asserts a false thing."

It must be borne in mind that Camden was no great Celtic or Saxon scholar. He took up those languages after he began his Britannia, because he found he corld not get on without them. He seems to have known about enough of Celtic to make him plunge at the wurd Aufona as a happy thought. 
We find then no real authority for altering the word Antona, either in MSS. or anything else. This being the case, our present argument is simply this :-

1. That Tacitus was quite correct in writing Antona.

2. That the Nene, or at least the upper part of it above Wellingborough, was called Anton, or something like it, by the Britons.

3. That the town in which we are, got its name from the river, and is Celtic, and not Saxon in its origin.

I shall endeavour to prove this triple proposition as briefly as I can, from a consideration of: $a$. Domesday; $b$. The parallel case of Southampton; $c$. The tradition of Anton still lingering on the Upper Nene; $d$. The meaning of the Celtic word Anton.

a. In Domesday Northampton is spelt Hantone, without the North, and the country Northantonescire. This Norman document is a treasure of phonetic spelling, and invaluable on this account. The Norman Commissioners had no bias, either to the Saxon or Celtic, and simply tried to write as near the sound as possible. "What is the name of your town, my good man?" "Anton" (pronounced Arnton)" Antone, please yer honour." " Do you spell it with an H?" "Thats mord nor I can say; we call it Hantone, and the Sheer we call North Antone Sheer." It is quite evident that the sound came with an $\mathrm{N}$, not an $\mathrm{M}$, from the natives, and the tradition of it is still kept up by our Northants. That it should gradually come to be written with an $\mathrm{M}$, and afterwards an $\mathrm{M} P$, is very natural. The Anglo-Saxon mind does not like incomprehensible words, and changes them if possible ; thus in the sailor's mouth, H.M. ship "Bellerophon" became "Billy Ruffian," and "Hirondelle," "Iron Devil." Besides, "Home" is a sacred word ; there is no place like "Hame" to the Saxon. On the smallest excuse they turned names into Ham. Thus the Celti-Scandinavian Dunholm became Durham; Brighthelmstone became Brighthamton before it cut itself down to Brighton. It would have been strange if Anton had not become Hamton.

b. Southampton (which no doubt gets the prefix South in contradistinction to this town) is, as to derivation, an exactly parallel case in every way. Camden's argument for the Celtic derivation of Southampton appears to me 
unanswerable, and makes my case, as regards Northampton, very much stronger. Southampton is in Domesday like this town, simply Hantone. The Roman town which preceded it, Camden, and other authorities, have concluded to have been the Clausentum of Antoninus. In the British tongue this would signify the port of Entum or Anton. Ptolemy calls Southampton water Trisanton (i.e., the bay of Anton, as Camden thinks), and Camden has a theory that the river Test (which is called in mediæval documents Terstan) was called (including Southampton water) Ant. or Anton, by the Britons, for he notices that many names of places on it have that prefix e.g. Andover (i.e., the ford over the And or Ant), Amport, \&c.

Now I was told by one antiquary whom I consulted about Antony in Cornwall, and Canton in Glamorganshire, that there is no such word as Anton in the Celtic, and that "the genius of the language is opposed to it." It will surprise my friend, and perhaps some others, to find that Camden's shot about the Test was remarkably close to the mark, for I find that that river is still called by the natives Anton in its upper branches, in this Year of Grace 1878.

I got this from a Hampshire clergyman, who lives not far from Andover. It is strange that Camden never heard of this local name; but it is much to his credit that he discovered it by the divination of genius. I have since found the name in an old county atlas. '

What is passing strange is that, with the word Antona staring him in the face in the Annals of Tacitus, and the town of Hantone doing the same in the pages of Domesday, he did not make the same brilliant shot about the Nene and its capital, as he did about the Test and its chief town. ${ }^{2}$

1 In a quaint old quarto, entitled "Viaje de Felipe Segundo a Inglaterra" by Andres Munoz, printed at Zaragoza, 1554 , and lately reprinted by the Madrid Bibliofilos (see a Review in the Athenceum of September 14th, 1878). Southampton is called Antona.

Anton is still to be met with as a patrunymic in England. In the Times police reports of September 3rd, 1878, will be found "Jabez Anton, 30, of 4, Cromwell Terrace, Birkbeck Road. Upper Hollo- way, a carman, was charged with causing the death of Ann Shaunahan, by run* ning over her head with a van, at Praed. street, \&c."

2 I have received an interesting communication from the Rev. Thomas Floud, Rector of Overton, Hants, pointing out other names, up country, evidently derived from the Anton. He also enclosed me an interesting MS. of Richd. Willis, an Andover antiquary of Q. Ann's reign, on this subject. 
c. Now, have we any vestiges existing, connected with the Nene, of the name Anton? I have discovered one in the name of a Hundred abutting on the Nene the Hundred of Hamfordshoe, which comprises Wellingborough, Doddington, Earls' Barton, and several other villages. In Domesday the word is written And-ferds-hoe -another case of phonetic spelling. I have had some correspondence with the Rev. Isaac Taylor, who, as is well known, is an authority on the subject of "Words and Places," and he thinks that this is a strong point in my favour.

This name comes from no town or village that ever was. The syllable ford gives us a clue to its paternity. A ford over what? Why it must be either over the Nene or the Ise, which latter stream bounds the hundred on the east. But there is not any definite Hoe next the Ise; while the hill on which Doddington stands, rears itself most conspicuously to onlookers from the high ground about Wollaston, and may well be called a Hoe. We conclude, therefore, that the name means the hill opposite the ford over the And. Now on the Hants Anton we find the same prefix And, representing Anton, in the word Andover. What does this And on the Nene mean if it does not mean the Ant or Anton? This is the only case that I have at present hit upon of the survival of the name Anton; but this instance is something in the way of cumulative evidence.

d. As to the meaning of Anton, Mr. Isaac Taylor writes me thus: "I am inclined to believe that Anton should be divided Ant-on, and not An-ton. If we look at Fich, Vergleich Woterbuch, i, 487, we see that Ant-on might be end water, boundary water, or frontier water; there being an old Keltic word ande, which answers to the Greek aैvra, a $\boldsymbol{v} \tau \boldsymbol{i}$, Latin ante, and English end, and which is seen in the German ent-gegen." In his book, Words and Places, Mr. Taylor has another theory for Anton, deriving it from aon-don, or ton; but this he appears to have given up for the revised opinion which I have read. That the Nene was an end, or frontier river, to two British kingdoms, is extremely likely. The marked valley in which it lies, as in a trough, for forty miles, and the forests which bristled on its further side 
for its whole length, together made it a very natural boundary of peoples. Probably the Iceni bordered it from the fen to Higham Ferrers. In the same way the Hants Anton may have been a boundary river in remote Celtic times; though I suppose the Belgæ had both sides of it in Roman times.

Of the derivation of Nene, Mr. Isaac Taylor writes: "As to the Nene, I am inclined with Ferguson to refer it to Nant, Valley, (in Welsh the $\mathrm{T}$ might drop off, as Cant $=100$, has become Can, see Rhys, Lecture ii). See on Nant, Fich, Vergleich Wort, \&c., where you will see that in Armorican Nannt takes the form Annt, the initial N dropping off. 'This makes it possible that Ant-on might have been Nant-on, the valley water." Then he refers to Ferguson, and concludes "your Andferdshoe is, I think, a strong point." He adds: "The great South African river being called the Vaal, i.e. the Valley, by the Dutch, is exactly parallel to the derivation of Nene from Nant." The name Nene, Morton says, is used in a tenth century charter. In old maps I find the Nene is sometimes written Neane, where we get the A, and this helps us on to Nant.

That a river should have one name at its mouth, and another up country, is quite a common thing. I have been at the trouble of hunting up about 450 named rivers of England, and find many instances of this, e.g. Thames-Isis, Humber-Ouse-Ure, Itchen-Alre, \&c.

As to towns in Britain being named from rivers, in Roman times, Isca Silurum, on the Isca, or Usk; Derventio, on the Derventio, or Derwent, might be cited.

That the Britons had a fort on the site of Northampton Castle seems probable, from its commanding position at the confluence of two streams, and from British pottery having been found there, as Mr. S. Sharp informs me

I much fear that I have written at too great length, but it is a suggestive subject, and full of matter. I had intended to have done a good deal of research in the British Museum and elsewhere, but have been quite prevented, by having had the superintendence of the diggings in the Ostorian Camp of Irchester, for the last seven weeks. 
I hope it will be understood that, though I do not mean to give up the theories I have propounded in this paper, in a hurry; yet I submit them with all deference, and in due humility, to those who know more than I do of the Science of Archæological Research. 